\title{
A Comparison of Perceived Use of the Metacognitive Reading Strategies by Iranian Master of Science Students for Hypertext and Printed Academic Materials
}

\author{
Sayyed Ali Ostovar-Namaghi \\ Shahrood University of Technology, Iran \\ Ali Ekrami Noghabi \\ Islamic Azad University, Science and Research Branch, Shahrood, Iran
}

\begin{abstract}
This study aims at finding out whether there are any significant differences between perceived use of the metacognitive reading strategies by Iranian Master of Science (MSc) students for hypertext and printed academic materials. To this end, fifty four students in total were randomly selected from MSc students of Gonabad University of Medical Sciences in Iran. Having received the research instruments, the subjects completed the demographic information sheet and two other questionnaires, i.e., the survey of reading strategies (SORS) and the online survey of reading strategies (OSORS). The researchers then used the SPSS software for data analysis. The results showed that research subjects reported a moderate perceived use of metacognitive reading strategies while reading academic hypertext and printed materials.
\end{abstract}

Index Terms-metacognitive reading strategies, hypertext and printed academic materials, master of science students

\section{INTRODUCTION}

On the one hand, English is the language of science, technology and medicine and on the other language education in many countries including Iran do not have enough time at their disposal to develop learners general proficiency, they focus on reading at the cost of other skills since it has the highest academic use and surrender value in EFL contexts. Despite the exclusive focus on reading, high school and university graduates in Iran do not enjoy a good command of reading. The researchers experience in both high school and university level created the theoretical sensitivity to hypothesize that students deficiency is due to the fact that our language education system makes students and teachers' cover very difficult texts and hypertexts in a very limited time and as such leaves no room for learner training or helping language learners learn how to tackle texts and hypertexts strategically. This study aims to uncover the differences between the metacognitive reading strategies used by learners for hypertext and printed academic materials, especially at the university level.

\section{Review of Related Literature}

Reading is a profound state of change and the traditional texts are not the only constructor of meaning. The Internet has reshaped our mode of reading from a linear to a more multimodal approach that requires new kind of competences (Burke \& Rowsell, 2008; Coiro \& Dobler, 2007). According to Rossman (2005), traditional textbooks are not in line with the future needs of learners; therefore, teachers have used the World Wide Web (WWW) to overcome this shortcoming, the most common hypertext, into their ESL instruction (Liou, 1997 \& Kasper, 2000). Similarly, the use of technology which aims at familiarizing learners with the challenge of reading various forms of electronic text is ever increasing(Lefever-Davis \& Pearman, 2005) or hypertext. A hypertext is "a kind of information environment in which textual materials and ideas are linked to one another in multiple ways" (Burbules \& Callister, 2000, p. 43).

In Iran where English is used as a foreign language, reading skill plays a vital role for Iranian MSc students in their academic context. They are required to read the MSc textbooks, articles in the international journals, magazines, CDs, eBooks, internet and other online materials in English although the medium of instruction is in Persian except for some limited number of international branches. In addition, most of the new academic knowledge and resources they need to acquire for improving their professional careers is mostly accessible in English.

According to Anderson (1991) in order to help students to handle their difficulties of reading in English, reading researchers and educators pay their attention to their reading process or the strategies they use rather than reading product or what is commonly known as reading comprehension. The term reading strategies is used to refer to conscious or subconscious procedures, actions, techniques that learners use to improve comprehension and interpretation of texts (O'Malley \& Chamot, 1990). Reading strategies indicate how readers conceive of a task, how 
they make sense of what they read, and what they do when they don't understand (Singhal, 2001). Oxford (1990) considered metacognitive strategies to be behaviours undertaken by the learners to plan, arrange, and assess their own learning.

Knowing the students' reading process or what reading strategy they use and how they use it when they encounter their reading difficulties can help teachers to know how to assist students to improve their abilities in reading (Aebersold \& Field, 1997). Recent research related to reading strategies have shown that depending on their level of proficiency learners use different strategies. Research studies using metacognitive reading strategy questionnaires revealed that there is a relationship between the students' reading proficiency and reading strategy use (Carrell: 1989 \& Monteiro, 1992). Carrell (1989) reported that good language learners use reading strategies to make up for lack of proficiency when they read texts.

In printed-text reading research, understanding learners reading strategies has led to the development of effective methods of intervention which aim at improving comprehension (Duke \& Pearson, 2002). Jafari \& Shokrpour (2012) showed that Iranian ESP students were using a limited number of strategies and their not even aware of this limited range. They suggested that second language reading teachers should instruct strategies explicitly that Iranian ESP students do not know.

To the best of my knowledge, there are no studies that investigate and compare the reading strategies of Iranian MSc students in relation to the type of texts i.e. printed text and hypertext. So while we know the importance of reading strategies, there is still a gap in our knowledge about the differences between the metacognitive reading strategies used by learners for hypertext and printed academic materials, especially at the university level and also the students' mastery level.

Anderson (2003) is one of the few researchers who have scrutinized this area of research. One of the few studies that have focused on this area of research is that conducted by Anderson (2003). He suggests that we gather reading strategies related to printed texts and hypertexts so as to better understand the differences and similarities between the strategy use in these two contexts. As teachers of English who would like to assist students in improving their ability of reading in English, we think that it should be useful to be aware of the reading strategies of students for these two types of texts and learn how to use them while reading to improve reading comprehension.

The current research is therefore conducted with Iranian MSc students to look at the differences and similarities in the perceived use of the metacognitive reading strategies used for hypertext and printed academic materials. This comparison may shed light on the influence of the length of the students' preparation program on the acquisition of reading strategies. Also it may propose such a program as a prerequisite for English classes.

This study will provide significant data to fill in this gap in the researches on how the increased application of hypertext and internet in academic settings can be handled and what reading strategies should be taken into consideration when teaching to read online. Also this is an attempt to extend the literature on reading strategies and it is response to the literacy needs of students in the near future.

Research Questions

This quantitative study was designed to investigate the differences between perceived use of the metacognitive reading strategies used by Iranian MSc students for hypertext and printed academic materials. More specifically, the study addresses the following questions:

1. Are there any significant differences between perceived use of the metacognitive reading strategies by Iranian MSc students for hypertext and printed academic materials in English?

2. What metacognitive reading strategies do Iranian MSc students use better when they are reading hypertext and printed academic materials in English?

3. How often do MSc students in different fields use hypertext metacognitive reading strategies and printed metacognitive reading strategies for academic materials in English?

4. Do perceived use of metacognitive reading strategies for printed and hypertext academic materials in English by Iranian MSc students vary due to gender?

Research Hypotheses

Based on the expected relationships among variables in the study, we stated these hypotheses:

1- There are not any significant differences between perceived use of the metacognitive reading strategies used by Iranian MSc students for hypertext and printed academic materials in English

2- Perceived use of the metacognitive reading strategies by Iranian MSc students when they are reading hypertext and printed academic materials in English are not different.

3- Perceived use of the metacognitive reading strategies by Iranian MSc students in different fields for hypertext and printed academic materials in English are the same.

4- There are not any significant differences between perceived use of the metacognitive reading strategies by Iranian male and female MSc students for hypertext and printed academic materials in English.

\section{Operational Definition of Variables}

Metacognitive reading strategies here are behaviours undertaken by the learners to plan, arrange, and assess their own learning. They are listed for printed and hypertext in appendix I and II. By hypertext/ online text we mean a computer-based text which can be read on the screen like textbooks, articles in the international journals, magazines, 
CDs, eBooks, internet and other online materials in English. Printed materials are those traditional materials that are presented by teachers on pages like books or pamphlets.

\section{MEthodologY}

\section{Subjects}

Fifty four students, 22 to 38 years old, in total were recruited for this study. The subjects were all MSc students of Gonabad University of Medical Sciences in Iran, and they were studying Emergency Nursing, Surgical Nursing and Health Education. It was voluntary to participate in the study. The students are 18 males and 36 females from different cities of Iran who are studying different MSc fields in Gonabad University of Medical Sciences. Their first language is Persian and they have studied English at high school for six or seven years and have passed one or two English courses at university and they had been engaged in a variety of printed and hypertext reading tasks in English. They are all available cases, so there is no explicit standard for choosing them as subjects for this study.

Data collection and analysis

To determine the kind of strategies used by students who had experiences of reading hypertext and printed academic materials, the Survey of Reading Strategies (SORS) (Sheorey and Mokhtari, 2001) and the Online Survey of Reading Strategies (OSORS) (Amer, 2010) were adapted for use in the present study. SORS (see appendix I) and OSORS (see appendix II) include three main types of strategies: global reading strategies; problem solving strategies; and support reading strategies.

The researchers translated these instruments into Persian and performed factor analysis. The reliability coefficient of the translated version of the instrument was found to be 0.80. Just like the original version, the Persian SORS instrument includes 30 items and Persian OSORS instrument consists of 34 items, and each item in both questionnaires made the learners specify the frequency which he or she uses that item. Items are rated on a Likert type scale ranging from 5 (always or almost always) to 1 (never or almost never) apply this strategy.

The respondents also filled out a demographic data sheet and SORS and OSORS questionnaires after a short talk about the aims of the research. Students who had experiences in reading passages in print or hypertext entered the study. In each class, after a short brief, students first completed the demographic data sheet and then, during 20 minutes, they completed the two reading strategies questionnaires.

In this study, statistical indices such as mean and standard deviation and statistical tests such as correlation coefficient, paired-samples T-test, independent-samples T-test and one way ANOVA were used.

\section{RESULTS}

Mokhtari \& Sheorey (2002) state that the SORS is scored on a fivepoint Likert scale in which scores of 2.4 or below demonstrate low strategy use, 2.5 to 3.4 show moderate strategy use, and 3.5 or above signifies high strategy use. Many scholars have found that learners use the strategies in moderate or high level (Oxford, 1995; Berkowitz and Cicchelli, 2004; Pang, 2008).

To answer the first question of the study, students' perceived use of global strategies, problem-solving strategies and support strategies for printed text were in "moderate level". It was the same for online text except for global strategies that found students as high strategy users. This is summarized in the table 1. It shows that there were no significant differences between these three different strategies for printed and hypertext.

TABLE 1:

MEAN SCORES FOR STUDENTS PERCEIVED USE OF PRINTED AND HYPERTEXT READING STRATEGIES (USING PAIRED-SAMPLES T- TEST)

\begin{tabular}{lllllll}
\hline Strategies & Texts & Mean & Std. Deviation & Std. Error Mean & t-value & p-Value \\
\hline \multirow{2}{*}{ Global } & printed & 3.47 & 0.635 & 0.120 & 0.801 \\
\multirow{3}{*}{ Problem-solving } & online & 3.52 & 0.579 & 0.109 & 0.135 & 0.694 \\
\cline { 2 - 6 } Support & printed & 3.48 & 0.719 & 0.138 & \multirow{2}{*}{0.4303} \\
& online & 3.40 & 0.734 & 0.142 & 0.143 & \multirow{2}{*}{0.764} \\
\cline { 2 - 6 } Total & printed & 3.22 & 0.756 & 0.118 & \multirow{2}{*}{0.312} \\
\hline
\end{tabular}

The second question aims to find out the most frequently used metacognetive reading strategies by Iranian students. Students selected problem-solving strategies for printed texts as the most used strategies such as re-reading for better understanding and getting back on track to concentrate. As it is shown in table 2, the subjects of this study also reported note-taking as one of the least use strategy. Also read aloud as another effective strategy is one of the least use strategies for both online and printed texts. 
TABLE 2:

THREE READING STRATEGIES USED MOST FREQUENTLY AND LEST FREQUENTLY BY STUDENTS FOR HYPERTEXT AND PRINTED TEXTS

\begin{tabular}{|c|c|c|c|c|}
\hline Text & Use & Strategies & Mean & Std. Deviation \\
\hline \multirow{6}{*}{ Printed } & \multirow{3}{*}{ MOST } & 25. When text becomes difficult, I reread to increase my understanding. & 3.82 & 1.090 \\
\hline & & \multirow{2}{*}{$\begin{array}{l}\text { 9. I try to get back on track when I lose concentration. } \\
14 \text {. When text becomes difficult, I pay closer attention to what I'm } \\
\text { reading. }\end{array}$} & 3.75 & 0.887 \\
\hline & & & 3.71 & 1.117 \\
\hline & \multirow{3}{*}{ LEAST } & $\begin{array}{l}\text { 5. When text becomes difficult, I read aloud to help me understand what I } \\
\text { read. }\end{array}$ & 2.67 & 1.218 \\
\hline & & $\begin{array}{l}\text { 13. I use reference materials such as (e.g. dictionary) to help me } \\
\text { understand what I read. }\end{array}$ & 3.03 & 1.170 \\
\hline & & 2. I take notes while reading to help me understand what I read. & 3.03 & 1.290 \\
\hline \multirow{6}{*}{ Hypertext } & \multirow{3}{*}{ MOST } & 1. I have a purpose in mind when I read on line. & 3.92 & 0.899 \\
\hline & & $\begin{array}{l}29 \text { I scan the on-line text to get a basic idea of whether it will serve my } \\
\text { purposes before deciding to read it. }\end{array}$ & 3.89 & 0.994 \\
\hline & & $\begin{array}{l}\text { 6. I think about whether the content of the on-line text fits my reading } \\
\text { purpose. }\end{array}$ & 3.85 & 0.848 \\
\hline & \multirow{3}{*}{ LEAST } & \multirow{3}{*}{$\begin{array}{l}\text { 2. I take notes while reading on-line to help me understand what I read. } \\
\text { 5. When on-line text becomes difficult, I read aloud to help me } \\
\text { understand what I read. } \\
\text { 7. I read slowly and carefully to make sure I understand what I am } \\
\text { reading on-line. }\end{array}$} & 2.82 & 1.055 \\
\hline & & & 2.82 & 1.248 \\
\hline & & & 2.85 & 1.007 \\
\hline
\end{tabular}

The third question focused on perceived use of the metacognitive reading strategies by Iranian MSc students in different fields. The subjects' perceived use of metacognitive reading strategies in different fields revealed that there were not any significant differences. The data were analyzed by means of one way ANOVA. The results are shown in table 3 .

TABLE3:

DIFFERENCES IN MEAN SCORES FOR STUDENTS PERCEIVED USE OF PRINTED AND HYPERTEXT READING STRATEGIES IN DIFFERENT FIELDS

\begin{tabular}{|c|c|c|c|c|c|c|}
\hline Texts & Strategies & Fields & Mean & Std. Deviation & Std. Error & p-Value \\
\hline \multirow{16}{*}{ Printed } & \multirow{4}{*}{ Global } & EmerNurs & 3.54 & 0.603 & 0.213 & \multirow{4}{*}{0.927} \\
\hline & & SurgNurs & 3.46 & 0.694 & 0.168 & \\
\hline & & Health & 3.38 & 0.526 & 0.303 & \\
\hline & & Total & 3.47 & 0.635 & 0.120 & \\
\hline & \multirow{5}{*}{ Problem-solving } & EmerNurs & 3.53 & 0.554 & 0.196 & \multirow{4}{*}{0.691} \\
\hline & & SurgNurs & 3.31 & 0.840 & 0.203 & \\
\hline & & Health & 3.61 & 0.577 & 0.333 & \\
\hline & & Total & 3.40 & 0.734 & 0.138 & \\
\hline & & EmerNurs & 3.61 & 0.625 & 0.221 & \multirow{4}{*}{0.220} \\
\hline & \multirow{3}{*}{ Support } & SurgNurs & 3.09 & 0.811 & 0.196 & \\
\hline & & Health & 2.92 & 0.449 & 0.259 & \\
\hline & & Total & 3.22 & 0.756 & 0.142 & \\
\hline & \multirow{4}{*}{ Total } & EmerNurs & 3.64 & 0.550 & 0.194 & \multirow{4}{*}{0.412} \\
\hline & & SurgNurs & 3.28 & 0.670 & 0.162 & \\
\hline & & Health & 3.32 & 0.553 & 0.319 & \\
\hline & & Total & 3.39 & 0.628 & 0.118 & \\
\hline \multirow{16}{*}{ Online } & \multirow{4}{*}{ Global } & EmerNurs & 3.58 & 0.433 & 0.153 & \multirow{4}{*}{0.947} \\
\hline & & SurgNurs & 3.50 & 0.637 & 0.154 & \\
\hline & & Health & 3.49 & 0.783 & 0.452 & \\
\hline & & Total & 3.52 & 0.579 & 0.109 & \\
\hline & \multirow{5}{*}{ Problem-solving } & EmerNurs & 3.79 & 0.609 & 0.215 & \multirow{4}{*}{0.265} \\
\hline & & SurgNurs & 3.30 & 0.745 & 0.180 & \\
\hline & & Health & 3.66 & 0.726 & 0.419 & \\
\hline & & Total & 3.48 & 0.719 & 0.135 & \\
\hline & & EmerNurs & 3.41 & 0.704 & 0.249 & \multirow{4}{*}{0.357} \\
\hline & \multirow{3}{*}{ Support } & SurgNurs & 3.18 & 0.818 & 0.198 & \\
\hline & & Health & 2.66 & 0.293 & 0.169 & \\
\hline & & Total & 3.19 & 0.760 & 0.143 & \\
\hline & \multirow{4}{*}{ Total } & EmerNurs & 3.51 & 0.497 & 0.176 & \multirow{4}{*}{0.745} \\
\hline & & SurgNurs & 3.33 & 0.662 & 0.160 & \\
\hline & & Health & 3.25 & 0.539 & 0.311 & \\
\hline & & Total & 3.37 & 0.595 & 0.112 & \\
\hline
\end{tabular}

For the last question, we tried to find differences between perceived use of the metacognitive reading strategies used by Iranian male and female MSc students for hypertext and printed academic materials. Using independent-samples Ttest in table 4 shows that there were no statistically significant differences between the means of males and females students on the three types of strategies as well as on the overall mean of strategies. Moreover, students' gender in different fields did not affect the perceived use of strategies in our study. 
TABLE 4:

MEAN SCORES FOR MALE AND FEMALE STUDENTS PERCEIVED USE OF PRINTED AND HYPERTEXT READING STRATEGIES

\begin{tabular}{|c|c|c|c|c|c|c|}
\hline Strategies & Texts & Gender & Mean & Std. Deviation & Std. Error Mean & p-Value \\
\hline \multirow{4}{*}{ Global } & \multirow{2}{*}{ Printed } & Male & 3.21 & 0.698 & 0.285 & \multirow[t]{2}{*}{0.426} \\
\hline & & Female & 3.55 & 0.614 & 0.130 & \\
\hline & \multirow{2}{*}{ Online } & Male & 3.13 & 0.705 & 0.288 & \multirow[t]{2}{*}{0.151} \\
\hline & & Female & 3.63 & 0.507 & 0.108 & \\
\hline \multirow{4}{*}{ Problem-solving } & \multirow{2}{*}{ Printed } & Male & 3.33 & 0.590 & 0.240 & \multirow[t]{2}{*}{0.397} \\
\hline & & Female & 3.42 & 0.779 & 0.166 & \\
\hline & \multirow{2}{*}{ Online } & Male & 3.27 & 0.800 & 0.326 & \multirow[t]{2}{*}{0.763} \\
\hline & & Female & 3.53 & 0.705 & 0.150 & \\
\hline \multirow{4}{*}{ Support } & \multirow[b]{2}{*}{ Printed } & Male & 3.22 & 0.916 & 0.374 & \multirow[t]{2}{*}{0.370} \\
\hline & & Female & 3.22 & 0.732 & 0.156 & \\
\hline & \multirow{2}{*}{ Online } & Male & 3.11 & 0.840 & 0.343 & \multirow[t]{2}{*}{0.552} \\
\hline & & Female & 3.21 & 0.756 & 0.161 & \\
\hline \multirow{4}{*}{ Total } & \multirow{2}{*}{ Printed } & Male & 3.23 & 0.786 & 0.321 & \multirow[t]{2}{*}{0.195} \\
\hline & & Female & 3.43 & 0.592 & 0.126 & \\
\hline & \multirow[b]{2}{*}{ Online } & Male & 3.19 & 0.686 & 0.280 & \multirow{2}{*}{0.417} \\
\hline & & Female & 3.42 & 0.575 & 0.122 & \\
\hline
\end{tabular}

\section{DisCUSSION}

This study aimed to find the differences between perceived use of the metacognitive reading strategies by Iranian MSc students for hypertext and printed academic materials in English. Oxford (1995) claims that students' strategies usage increases when they are in upper classes, but the result of this research was different. Quite the opposite of what the researchers expected, there was not a significant difference between lower and upper classes ( $p>0.05)$.

It is noteworthy that students' perceived use of global strategies, problem-solving strategies and support strategies for printed text were in "moderate level". And it was the same for online text except for global strategies that found students as high strategy users. Their experiences can account for this.

Karbalaei (2010) suggested that students are not well versed in employing various useful and effective strategies for better comprehension such as summarizing, underlining, or note-taking. This is similar to our findings. Note-taking was as one of the least use strategy in this study.

Amer (2010) concluded that there were no statistically significant differences between the means of first and fourth-year males and females on the three types of strategies as well as on the overall mean of strategies that is in accordance to this study. This result is also consistent with the recent researches on gender and reading strategies (Phakiti, 2003; Poole, 2005).

\section{CONCLUSION AND IMPLICATIONS FOR FURTHER RESEARCH}

For meaningful education, it is very important to improve the reading proficiency of learners in English. So it is important to examine developments in the theories and practices for insights that can help us bring about significant changes in reading pedagogy in Iran. As we know metacognitive strategies are necessary for this change. As the results of this study show, Iranian MSc students are moderate users of metacognitive reading strategies so adding reading strategy instruction classes for Iranian students at the beginning of their academic study seems to be necessary. Also students in colleges and universities can be encouraged to attend reading strategy classes.

Statistical analyses revealed that there is not a significant difference in the total number of strategies used by the three groups. Thus, all the students were moderate users of reading strategies except in global strategies for online text that found students as high strategy users. Because one of the necessary techniques which readers should employ to understand the text is using reading strategies, and according to the findings of this research it is suggested that we as teachers should note reading strategy instruction when teaching to read. This may lead to better reading performances, too. Teachers should also give more attention to the least frequently used strategies reported in this study.

The subjects' level of proficiency in English selected for this research and the numbers of them are the main reasons that make me cautious about the generalizability of the findings. The extent to which these findings can be generalized to all students at different fields and levels is still uncertain. Among other things, the researchers recommend that interested researchers: (1) examine the instructional effectiveness of different printed and online reading strategies used by male or female students who possess different learning styles; (2) work with subjects studying different courses or using different materials i.e. academic and non-academic and comparing the results with their genders or ages.

\section{ACKNOWLEDGEMENT}

We would like to thank Dr. Mojtaba Kianmehr for her statistical guidance. Special thanks also to the Head of Gonabad University of Medical Sciences and all the students who participated in this study for their assistance. 
Directions: Listed below are statements about what people do when they read academic or school-related materials such as textbooks or library books. Five numbers follow each statement $(1,2,3,4,5)$, and each number means the following:

- 1 means "I never or almost never do this."

- 2 means "I do this only occasionally."

- 3 means "I sometimes do this" (about $\mathbf{5 0 \%}$ of the time).

- 4 means "I usually do this."

- 5 means "I always or almost always do this."

After reading each statement, circle the number $(1,2,3$, 4, or 5) that applies to you using the scale provided. Please note that there are no right or wrong answers to the statements in this inventory.

1. I have a purpose in mind when I read.

2. I take notes while reading to help me understand what I read.

3. I think about what I know to help me understand what I read.

4. I take an overall view of the text to see what it is about before reading it.

5. When text becomes difficult, I read aloud to help me understand what I read.

6. I think about whether the content of the text fits my reading purpose.

7. I read slowly but carefully to be sure I understand what I'm reading.

8. I review the text first by noting its characteristics like length and organization.

9. I try to get back on track when I lose concentration.

10. I underline or circle information in the text to help me remember it.

11 . I adjust my reading speed according to what I'm reading.

12. When reading, I decide what to read closely and what to ignore.

13. I use reference materials such as (e.g. dictionary) to help me understand what I read.

14. When text becomes difficult, I pay closer attention to what I'm reading.

15. I use tables, figures, and pictures in text to increase my understanding.

16. I stop from time to time and think about what I'm reading.

17. I use context clues to help me better understand what I'm reading.

18. I paraphrase (restate ideas in my own words) to better understand what I read.

19. I try to picture or visualize information to help remember what I read.

20. I use typographical aids like boldface and italics to identify key information.

21 . I critically analyze and evaluate the information presented in the text.

22. I go back and forth in the text to find relationships among ideas in it.

23. I check my understanding when I come across new information.

24. I try to guess what the material is about when I read.

25 . When text becomes difficult, I reread to increase my understanding.

26. I ask myself questions I like to have answered in the text.

27. I check to see if my guesses about the text are right or wrong.

28. When I read, I guess the meaning of unknown words or phrases.

29. When reading, I translate from English into my native language.

30. When reading, I think about information in both English and my mother tongue.

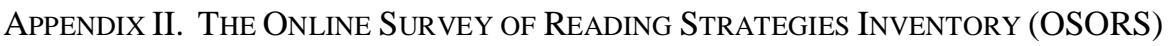

Directions: Listed below are statements about what people do when they read online academic or school-related materials such as ebooks or articles from internet. Five numbers follow each statement $(1,2,3,4,5)$, and each number means the following:

- 1 means "I never or almost never do this."

- 2 means "I do this only occasionally."

- 3 means "I sometimes do this" (about 50\% of the time).

- 4 means "I usually do this."

- 5 means "I always or almost always do this."

After reading each statement, circle the number $(1,2,3,4$, or 5$)$ that applies to you using the scale provided. Please note that there are no right or wrong answers to the statements in this inventory.

Original article at: http://ijedict.dec.uwi.edu//viewarticle.php?id=1159

\section{Global Strategies (17)}

1 I have a purpose in mind when I read on line

3 I think about what I know to help me understand what I read on-line

4 I take an overall view of the on-line text to see what it is about before reading it

6 I think about whether the content of the on-line text fits my reading purpose

8 I review the on-line text first by noting its characteristics like length and organization

12 When reading on-line, I decide what to read thoroughly and what to ignore 
14 When on-line text becomes difficult, I pay closer attention to what I am reading

15 I use tables, figures, and pictures in the on-line text to increase my understanding

17 I use context clues to help me better understand what I am reading online

20 I use typographical features like bold face and italics to identify key information.

21 I critically analyze and evaluate the information presented in the on-line text.

23 When reading on-line, I check my understanding when I come across new information.

24 I try to guess what the content of the on-line text is about when I read.

27 I check to see if my guesses about the on-line text are right or wrong

29 I scan the on-line text to get a basic idea of whether it will serve my purposes before deciding to read it.

30 I critically evaluate the on-line text before choosing to use its information

32 When reading on-line, I look for sites that cover both sides of an issue.

Problem-solving strategies (8)

7 I read slowly and carefully to make sure I understand what I am reading on-line.

9 I try to get back on track when I lose concentration

11 I adjust my reading speed according to what I am reading on-line

16 I stop from time to time and think about what I am reading on-line

19 I try to picture or visualize information to help remember what I read on-line.

25 When on-line text becomes difficult, I re-read it to increase my understanding.

28 When I read on-line, I guess the meaning of unknown words or phrases

31 I can distinguish between fact and opinion in on-line texts

\section{Support Strategies (9)}

2 I take notes while reading on-line to help me understand what I read

5 When on-line text becomes difficult, I read aloud to help me understand what I read

10 I print out a hard copy of the on-line text then underline or circle information to help me remember it.

13 I use reference materials (e.g. an on-line dictionary) to help me understand what read on-line.

18 I paraphrase (restate ideas in my own words) to better understand what I read on-line.

22 I go back and forth in the on-line text to find relationships among ideas in it

26 I ask myself questions I like to have answered in the on-line text

33 When reading on-line, I translate from English into my native language

34 When reading on-line, I think about information in both English and my mother tongue

\section{REFERENCES}

[1] Aebersold, J.A., Field, M.L. (1997). From Reader to Reading Teacher: Issues and Strategies for Second Language Classrooms. Cambridge University Press, New York.

[2] Amer, A. Al Barwani, T. \& Ibrahim, M. (2010). Student teachers' perceived use of online reading strategies. International Journal of Education and Development using Information and Communication Technology (IJEDICT), 6 (4), $102-113$.

[3] Anderson, N.J. (1991). Individual differences in strategy use in second language reading and testing. The Modern Language Journal, 75 (2), 460-472.

[4] Anderson, N. J. (2003). Scrolling, clicking and reading English: Online reading strategies in a second/foreign language. The Reading Matrix: An International Online Journal, 3(3), 1-33.

[5] Berkowitz, E. and Cicchelli, T. (2004). Metacognitive strategy use in reading of gifted high achieving and gifted under achieving middle school students in new york city. Education and Urban Society, 37, 37-57.

[6] Burbules, N. C., \& Callister, T. A. (2000). Watch it: The risks and promises of information technologies for education. Boulder, CO: Westview.

[7] Burke, A., \& Rowsell, J. (2008). Screen pedagogy: Challenging perceptions of digital reading practice. Changing English: Studies in Culture \& Education, 15(4), 445-456.

[8] Carrell, P. (1989). Metacognitive awareness and second language reading. The Modern Language Journal, 73 (2), 121-134.

[9] Coiro, J., \& Dobler, E. (2007). Exploring the online reading comprehension strategies used by sixth-grade skilled readers to search for and locate information on the Internet. Reading Research Quarterly, 42(2), 214-257.

[10] Duke, N.K., \& Pearson, P.D. (2002). Effective practices for developing reading comprehension. In A.E. Farstup \& S.J. Samuels (Eds.), What research has to say about reading instruction (pp. 205-242). Newark, DE: International Reading Association.

[11] Jafari, M. \& Shokrpour, N. (2012). The Reading Strategies Used by Iranian ESP Students to Comprehend Authentic Expository Texts in English. International Journal of Applied Linguistics \& English Literature. 1 (4), 102-113

[12] Karbalaei, A. (2010). A Comparison of the Metacognitive Reading Strategies Used by EFL and ESL Readers. The Reading Matrix. 10 (2), 165-180

[13] Kasper, L. F. (2000). New technologies, new literacies: Focus discipline research and ESL learning communities. Language Learning and Technology, 4 (2), 105-128.

[14] Lefever-Davis, S., \& Pearman, C. (2005). Early readers and electronic texts: CD: ROM storybook features that influence reading behaviors. The Reading Teacher, 58, 446-454.

[15] Liou, H. (1997). The impact of WWW texts on EFL learning. Computer Assisted Language Learning, 10 (5), $455-478$.

[16] Mokhtari K.. \& Sheorey, R. (2002). Measuring ESL students' awareness of reading strategies. Journal of Developmental Education, 25 (3), 2-10. 
[17] Monteiro, S.Q. (1992). A contrastive investigation of reading strategy awareness and reading strategy use by adolescents reading in the first language (Portuguese) and in the foreign language (English). Unpublished doctoral thesis. Essex University

[18] O’Malley, J.M. \& Chamot, A. (1990). Learning strategies in second language acquisition. Cambridge: Cambridge University Press.

[19] Oxford, R. (1990). Language Learning Strategies. Boston, Mass.: Heinle \& Heinle

[20] Oxford, R., \& Burry-Stock, J. (1995). Assessing the use of language learning strategies worldwide with the ESL/EFL version of the strategy inventory for language learning SILL. System, 23, 1-23.

[21] Pang, J. (2008). "Research on good and poor reader characteristics: Implication for L2 reading research in China". Reading in a Foreign Language, 20 (1), 1-18.

[22] Phakiti, A. (2003). A closer look at gender and strategy use in L2 reading. Language Learning, 53, 649-702.

[23] Poole, A. (2005). Gender Differences in Reading Strategy Use Among ESL College Students. Journal of College Reading and Learning, 36 (1), 7-20.

[24] Rossman, P. (2005). Beyond the book: electronic textbooks will bring worldwide learning. The Futurist, 38, 18-23.

[25] Singhal, M. (2001). "Reading proficiency, reading strategies, metacognitive awareness and L2 readers". The Reading Matrix, $1(1), 1-15$.

[26] Sheorey, R., \& Mokhtari, K. (2001). Differences in the metacognitive awareness of reading strategies among native and nonnative readers. System, 29, 431-449.

Seyyed Ali Ostovar-Namaghi is an associate professor of TEFL at Shahrood University of Technolog. His chief research interest is language teacher knowledge. He has published in a number of leading peer-reviewed journals including: The Reading Matrix (California), Teacher Education Quarterly (California), The Qualitative Report (Florida), The Asian EFL Journal (Korea), Journal of Langauge Teaching and Research (Finland), Theory and Practice in Language Teaching (Finland), and Sino-Us Foreign Language (Ohaio), International Journal of Applied Linguistics and English Literature (Australia). Presently he runs courses in EAP at Shahrood University of Technology.

Ali Ekrami Noghabi was born in Gonabad, Iran in 1973. He has obtained his BA in Language Teaching from Islamic Azad University, Torbat branch. Now he is an MA student of Teaching English in Science and Research Branch, Islamic Azad University, Shahrood, Iran. He works as research affair officer in Gonabad University of Medical Sciences, Gonabad, Iran. His research interests include college reading and writing and discovering the value of using hypertext. 